Anna Piszcz

\title{
CZYNNIK CZASU W PRAWIE ANTYMONOPOLOWYM
}

I. Różnorodne instytucje prawa antymonopolowego mogą być analizowane w jednym opracowaniu ze względu na wspólny dla nich czynnik czasu. Mnogość i różnorodność pojawiających się na gruncie prawa antymonopolowego zagadnień związanych z czynnikiem czasu skłania do tego, by już na wstępie wprowadzić pewną ich klasyfikację. Układają się one w zasadzie w cztery podstawowe grupy.

Pierwsza obejmuje czas w materialnym prawie antymonopolowym. Przykładowo wskazać tu można czynnik czasu występujący w wyłączeniach spod zakazu porozumień ograniczających konkurencję, w ocenie przesłanek powstania obowiązku zgłoszenia zamiaru koncentracji, w ocenie przesłanek wpływających na wysokość kary pieniężnej, w instytucji przedawnienia, czy też czasowy wymiar rynku właściwego. Druga grupa obejmuje przypadki, gdy czynnik czasu sytuuje się w płaszczyźnie procesowego prawa antymonopolowego, w tym w szczególności w terminach i czasie trwania (szybkości) postępowania antymonopolowego. Trzecią grupę tworzą przypadki, w których czas występuje w ustrojowym prawie antymonopolowym, zwłaszcza gdy chodzi o kadencyjność (bądź jej brak) organu antymonopolowego. Czwarta wreszcie odrębna grupa, wyodrębniona przez potrzebę wyeksponowania problematyki historycznoprawnej, gromadzi zagadnienia ewolucji prawa antymonopolowego.

Pełne omówienie wszystkich wskazanych wyżej, zróżnicowanych zagadnień związanych z czynnikiem czasu na gruncie prawa antymonopolowego wymagałoby większej rozprawy wykraczającej poza wąskie ramy artykułu. Stąd też na użytek niniejszego opracowania niezbędne jest wprowadzenie ograniczeń materiału, który będzie przedmiotem dalszych rozważań. Skupią się one mianowicie w szczególności na wybranych zagadnieniach z zakresu materialnego prawa antymonopolowego oraz w niewielkim zakresie - procesowego prawa antymonopolowego. Konieczność zachowania skrótowej postaci opracowania skłania również do ograniczenia jego zakresu do polskiego prawa antymonopolowego, choć oczywiście czynnik czasu występuje licznie i w innych systemach ochrony konkurencji, krajowych i ponadnarodowych. 
II. Już w przepisach ogólnych ustawy z dnia 16 lutego 2007 r. o ochronie konkurencji i konsumentów ${ }^{1}$ (dalej: u.o.k.k.) odnajdujemy czynnik czasu. Otóż w ustawowym „słowniczku” w art. 4 w pkt 11 umieszczona została definicja konkurentów, zgodnie z którą rozumie się przez to przedsiębiorców, którzy wprowadzają lub mogą wprowadzać albo nabywają lub mogą nabywać, w tym samym czasie, towary na rynku właściwym. Z powyższego sformułowania wywodzi się pośrednio wymiar czasowy rynku właściwego².

Podkreślenia wymaga, że wymiar ten nie wynika z samej definicji rynku właściwego (art. 4 pkt 9 u.o.k.k.), która przewiduje jedynie aspekt produktowy i aspekt geograficzny rynku. Nie powinno jednak budzić wątpliwości, że struktura rynku właściwego winna być ustalana na chwilę, w której doszło do danego zachowania przedsiębiorcy podlegającego ocenie celem zakwalifikowania go jako naruszenie przepisów prawa antymonopolowego albo jako zachowanie przepisów tych nienaruszające. Do ustalenia, czy dane zachowanie przedsiębiorcy stanowiło nadużycie pozycji dominującej, konieczne jest ustalenie, czy pozycja dominująca tegoż przedsiębiorcy w dacie analizowanego zachowania w ogóle istniała, jaka była w tej dacie struktura rynku, w tym udział przedsiębiorcy w rynku w porównaniu do udziału jego konkurentów. O ile szereg rynków nie wykazuje tendencji do zmian strukturalnych i cechuje się względną stabilnością, bywają i sytuacje, w których udział przedsiębiorcy w rynku właściwym podlega istotnym wahaniom w czasie. I tutaj wymiar czasowy rynku musi zaznaczyć się najdobitniej, staje się elementem niezbędnym. Przedsiębiorca może zyskiwać pozycję dominującą (albo przeciwnie - tracić ją) jedynie przejściowo $\mathrm{w}$ związku z okresowymi niedoborami określonych towarów bądź usług (np. kryzysem paliwowym) bądź inną trudną sytuacją gospodarczą, czy z wydarzeniami takimi, jak targi, imprezy sportowe, festyny itp. W konsekwencji wyłania się trzeci aspekt rynku właściwego, tj. aspekt czasowy, który musi być badany przez Prezesa Urzędu Ochrony Konkurencji i Konsumentów ${ }^{3}$ jako organ antymonopolowy, by w prowadzonym przez niego postępowaniu prawidłowo odtworzyć strukturę rynku i jej historię w okresie badanym przez organ.

Możliwe jest też odnoszenie czasowego wymiaru rynku właściwego do czasu trwania danego rynku. Ujęcie takie wydaje się mieć istotne znaczenie. Zdarzają się bowiem sytuacje, gdy powstają odrębne rynki, funkcjonujące jedynie przez krótki okres. Warto przypomnieć w tym miejscu wyrok Sądu Antymonopolowego z dnia 7 kwietnia 1999 r. ${ }^{4}$, w którym Sąd podzielił ustalenie Prezesa UOKiK, iż rynkiem właściwym był rynek udostępniania, wynajmu terenu na prowadzenie działalności handlowej na pasie drogowym zajętym przez organizatora Jarmarku św. Dominika,

Dz.U. Nr 50, poz. 331 z późn. zm.

Por. T. Skoczny, (w:) red. T. Skoczny, Ustawa o ochronie konkurencji i konsumentów. Komentarz, Warszawa 2009, s. 216.

Dalej: UOKiK.

XVII Ama 89/98, „Wokanda” 2000, nr 9, s. 52. 
który to rynek został ograniczony do okresu 2-17 sierpnia 1997 r., tj. czasu trwania Jarmarku. Takie „krótkookresowe” rynki mogą być kłopotliwe przy ocenie przez Prezesa UOKiK wyłączenia porozumień spod zakazu porozumień ograniczających konkurencję z uwagi na niski udział rynkowy (tzw. porozumień bagatelnych), w przypadku których badać należy udział stron porozumienia w rynku posiadany przez nie w roku kalendarzowym poprzedzającym zawarcie porozumienia, co jest możliwe, gdy chodzi o rynki wyznaczane w kontekście dłuższego okresu (istniejące w okresie dłuższym niż dany rok kalendarzowy).

Ustawa niejednokrotnie posługuje się pojęciem roku, w tym roku poprzedzającego. Przy tym stosowane są różne kategorie roku:

1) rok rozliczeniowy (art. 106, 109, 110 u.o.k.k.),

2) rok kalendarzowy (art. 5, 7 u.o.k.k.) rozumiany jako pełny rok o danym numerze, np. rok 2010, okres od 1 stycznia do 31 grudnia,

3) rok obrotowy (art. 13, 14 pkt 1 u.o.k.k.),

4) rok podatkowy (art. 4 pkt 15 u.o.k.k.),

5) rok - bez żadnego przymiotnika, co oznacza jedną z dwóch kategorii roku:

- rok kalendarzowy (art. 76, 93 u.o.k.k.) rozumiany, jak wskazano wyżej, albo

- rok rozumiany jako termin, okres 365 dni (chyba że w grę wchodzi rok przestępny) między dwiema jednakowymi (chyba że w grę wchodzi rok przestępny) datami dziennymi i miesięcznymi w kalendarzu (art. 14 pkt 2, art. 21, 22, 23 u.o.k.k.); zgodnie $\mathrm{z}$ art. 112 Kodeksu cywilnego ${ }^{5}$, termin oznaczony w latach kończy się z upływem dnia, który datą odpowiada początkowemu dniowi terminu, a gdyby takiego dnia w ostatnim miesiącu nie było w ostatnim dniu tego miesiąca ${ }^{6}$.

Kategoria roku rozliczeniowego ma istotne znaczenie z punktu widzenia ustalania wysokości kar pieniężnych nakładanych na przedsiębiorców. Zgodnie z art. 106 ust. 1 u.o.k.k., za wymienione w nim zachowania Prezes UOKiK może nałożyć na przedsiębiorcę, w drodze decyzji, karę pieniężną w wysokości nie większej niż $10 \%$ przychodu osiagniętego w poprzedzającym rok nałożenia kary roku rozliczeniowym. Jednocześnie w art. 106 ust. 4 u.o.k.k. wymiar kary oderwano od wyników przedsiębiorcy odnośnie do przypadków, w których w poprzednim roku rozliczeniowym przychód u danego przedsiębiorcy w ogóle nie zaistniał.

$5 \quad$ Ustawa z dnia 23 kwietnia 1964 r. - Kodeks cywilny, Dz.U. Nr 16, poz. 93 z późn. zm.; dalej: kc.

6 Ten sposób obliczania terminu rocznego na gruncie u.o.k.k. stosujemy na podstawie art. 110 kc., zgodnie z którym, jeżeli ustawa oznacza termin, nie określając sposobu jego obliczania, stosuje się przepisy art. 111 i nast. kc. 
Warto natomiast zauważyć, że w wspomnianej wyżej regulacji wyłączenia spod zakazu porozumień ograniczających konkurencję tzw. porozumień bagatelnych (zasada de minimis) brak jest jakiejkolwiek wskazówki co do tego, jak należy postapić w przypadku, gdy w roku kalendarzowym poprzedzającym zawarcie porozumienia dany rynek w ogóle nie istniał. W literaturze twierdzi się, że w przypadku nieistnienia danego rynku w roku kalendarzowym poprzedzającym zawarcie porozumienia nie można uznać, że udział stron porozumienia w rynku wynosił $0 \%$ i że w związku $\mathrm{z}$ tym porozumienie korzysta $\mathrm{z}$ wyłączenia, o którym mowa w art. 7 ust. 1 u.o.k.k. ${ }^{7}$ $\mathrm{Z}$ drugiej jednak strony przyjęcie tezy o niestosowaniu art. 7 ust. 1 u.o.k.k. w takich przypadkach budzi zastrzeżenia z perspektywy przedsiębiorców działających na rynkach nowych (dopiero wykreowanych) czy „krótkookresowych”.

Trudno mówić o równości w traktowaniu przedsiębiorców, gdy tylko ci, którzy działają na rynkach powstałych nie później niż w poprzednim roku, mogliby korzystać z dobrodziejstwa zasady de minimis. Być może „złoty środek” w takich przypadkach mogłoby stanowić ustalanie udziałów w rynku w roku zawarcia porozumienia. Prezes UOKiK w jednej ze swych decyzji ${ }^{8}$ odnoszenie się do roku zawarcia porozumienia dla potrzeb zastosowania zasady de minimis uznał co prawda za obarczone błędem, jednak z uzasadnienia decyzji nie wynika, aby chodziło w sprawie o rynek, który w poprzednim roku kalendarzowym w ogóle nie istniał.

Jeśli chodzi o czynnik czasu użyty w przepisach statuujących zasadę de minimis, należy zwrócić uwagę na jeszcze jedną kwestię. Otóż udziały w rynku należy ustalać w odniesieniu do roku kalendarzowego. Może być to utrudnione w przypadku, gdy rok obrotowy przedsiębiorcy nie pokrywa się z rokiem kalendarzowym, gdyż istotnym źródłem informacji o udziale przedsiębiorcy w rynku są jego sprawozdania finansowe, sporządzane za poszczególne lata obrotowe. Jednakże posłużenie się przez ustawodawcę koncepcją roku obrotowego w art. 7 ust. 1 u.o.k.k. mogłoby komplikować sprawę jeszcze bardziej, gdyby zaistniała potrzeba ustalania łącznego udziału konkurentów w rynku w danym roku obrotowym (zob. art. 7 ust. 1 pkt 1 u.o.k.k.). W przypadku, gdyby mieli oni w różny sposób obrany rok obrotowy, trudno byłoby przesądzić, do którego okresu odnieść się, ustalając ten udział.

III. W myśl art. 3 pkt 9 ustawy o rachunkowości ${ }^{9}$ pod pojęciem roku obrotowego rozumie się rok kalendarzowy lub inny okres trwający 12 kolejnych pełnych miesięcy kalendarzowych, stosowany również do celów podatkowych. Określenie „rok obrotowy" pojawia się w art. 13 ust. 1 i ust. 2 pkt 4 u.o.k.k., przy czym jego użycie nie budzi kontrowersji. Powstaje natomiast pytanie, czy użyte w art. 106 i nast.

Tak C. Banasiński, E. Piontek (red.), Ustawa o ochronie konkurencji i konsumentów. Komentarz, Warszawa 2009, s. 225.

8 Decyzja z dnia 11 lipca 2007 r., nr RKT-21/2007.

9 Ustawa z dnia 29 września 1994 r. o rachunkowości, Dz.U. z 2009 r. Nr 152, poz. 1223 z późn. zm. 
u.o.k.k. pojęcie roku rozliczeniowego można traktować jako synonim roku obrotowego. Pułap kary pieniężnej nakładanej przez Prezesa UOKiK na przedsiębiorcę na podstawie art. 106 ust. 1 u.o.k.k. stanowi 10\% przychodu osiagniętego w poprzedzającym rok nałożenia kary roku rozliczeniowym. Przychód został zdefiniowany w art. 4 pkt 15 u.o.k.k. jako przychód uzyskany w roku podatkowym poprzedzającym dzień wszczęcia postępowania na podstawie u.o.k.k. w rozumieniu obowiązujących przedsiębiorcę przepisów o podatku dochodowym. Tym samym, mówiąc w art. 106 i nast. u.o.k.k. o roku rozliczeniowym, ustawodawca miał na myśli rok podatkowy. Co prawda pojęcia roku podatkowego i roku obrotowego są ze sobą ściśle powiązane, jednak w praktyce mogą zaistnieć sytuacje, gdy rok podatkowy i rok obrotowy nie pokryją się ze sobą (rozważania w tym przedmiocie wykraczają poza ramy niniejszego opracowania). W przypadku osób prawnych, w myśl art. 8 ustawy o podatku dochodowym od osób prawnych, ${ }^{10}$ rokiem podatkowym jest co do zasady rok kalendarzowy, chyba że podatnik postanowi inaczej w statucie albo w umowie spółki, albo w innym dokumencie odpowiednio regulującym zasady ustrojowe innych podatników i zawiadomi o tym właściwego naczelnika urzędu skarbowego; wówczas rokiem podatkowym jest okres kolejnych dwunastu miesięcy kalendarzowych. Z kolei w przypadku osób fizycznych rokiem podatkowym zawsze jest rok kalendarzowy ${ }^{11}$.

Do art. 106 i nast. u.o.k.k. oraz art. 4 pkt 15 u.o.k.k. należałoby zaproponować dwie zmiany:

- w art. 106 i nast. u.o.k.k. należałoby określenie „rok rozliczeniowy” zastąpić określeniem „rok podatkowy”;

- w art. 4 pkt 15 u.o.k.k. należałoby wykreślić wyrazy „poprzedzającym dzień wszczęcia postępowania na podstawie ustawy”; przepisy art. 106 i nast. u.o.k.k. wskazują bowiem, że przy wymiarze kary uwzględnia się przychód w roku poprzedzającym rok nałożenia kary, zaś zdefiniowane w art. 4 pkt 15 u.o.k.k. pojęcie przychodu nie zostało w ustawie użyte do celów innych niż regulacja nakładania kar pieniężnych.

Powiązanie sankcji względnie oznaczonej z przychodem osiagniętym w roku rozliczeniowym poprzedzającym rok nałożenia sankcji nie jest jedynym zabiegiem ustawodawcy, polegającym na uzależnieniu wysokości kary od czynnika czasu. Bardziej klasyczny przykład takiej zależności stanowi system wymiaru dziennego kar pieniężnych z tytułu zwłoki w wykonaniu orzeczeń (kwestie dotyczące termi-

10 Ustawa z dnia 15 lutego 1992 r. o podatku dochodowym od osób prawnych, Dz.U. z 2000 r. Nr 54, poz. 654 z późn. zm.

11 Zgodnie z art. 11 ustawy z dnia 29 sierpnia 1997 r. - Ordynacja podatkowa, Dz.U. z 2005 r. Nr 8, poz. 60 z późn. zm. rokiem podatkowym jest rok kalendarzowy, chyba że ustawa podatkowa stanowi inaczej. Ustawa $z$ dnia 26 lipca 1991 r. o podatku dochodowym od osób fizycznych, Dz.U. z 2010 r. Nr 51, poz. 307, nie ustanawia wyjątku od wskazanej zasady. 
nów wykonania decyzji Prezesa UOKiK regulują przepisy art. 112-113 u.o.k.k.). Kary te naliczane są w wysokości równowartości do 10.000 euro za każdy dzień zwłoki, licząc od daty wskazanej w decyzji Prezesa UOKiK (art. 107 u.o.k.k.). O ile kary nakładane na podstawie art. 106 u.o.k.k. uzależnione są od przychodu osiagniętego w historycznym okresie, o tyle kary z tytułu zwłoki w wykonaniu orzeczeń są w pewnym sensie kształtowane przez stronę w teraźniejszości - im dłużej strona zwleka z wykonaniem decyzji, tym wyższa będzie naliczona kara. Teoretycznie wysokość takiej kary jest nieograniczona, jeśli tylko strona nie będzie wykonywała orzeczenia. Wydaje się, że taka konstrukcja kary służy skuteczności prawa antymonopolowego, spełniając szereg przypisanych jej funkcji, w tym funkcję egzekucyjną (przymuszająca) i funkcję represyjną.

Ostatni poruszany tutaj wątek związany z sankcjami pieniężnymi dotyczy przesłanek wysokości kary pieniężnej. Jedną z tych przesłanek, wymienionych $\mathrm{w}$ art. 111 u.o.k.k., jest okres naruszenia przepisów ustawy. Ustawa o ochronie konkurencji i konsumentów nie przewiduje co prawda podwyższania czy obniżania kary w określonym stopniu proporcjonalnie do długotrwałości czy krótkotrwałości naruszenia przepisów ustawy. Jednakże od 1 stycznia 2009 r. Prezes UOKiK stosuje opublikowane przez niego „Wyjaśnienia w sprawie ustalania wysokości kar pieniężnych za stosowanie praktyk ograniczających konkurencję"12.

W części 3 Wyjaśnień Prezes UOKiK zastrzega sobie prawo do zwiększenia tzw. kwoty bazowej kary (o 200\% kwoty bazowej w przypadku porozumień ograniczających konkurencję oraz o $100 \%$ w przypadku nadużywania pozycji dominującej), jeśli długotrwałość stosowania praktyki ograniczającej konkurencję prowadzi do zwielokrotnienia jej negatywnych skutków, w szczególności, gdy wpływa na wysokość korzyści uzyskiwanych przez przedsiębiorcę dopuszczającego się naruszenia lub szkody ponoszone przez innych uczestników rynku. Przy tym jako długotrwałe traktowane są naruszenia trwające dłużej niż 1 rok. Należy jednak wyraźnie podkreślić, że jakkolwiek Wyjaśnienia nie mają charakteru prawnie wiążącego, to sprzyjają transparentności polityki karania realizowanej przez Prezesa UOKiK. Dążenie organu antymonopolowego do przejrzystości działań podejmowanych wobec przedsiębiorców naruszających prawo antymonopolowe należy ocenić pozytywnie.

IV. Czynnik czasu w postaci terminu rocznego (względnie kilkuletniego), obliczanego zgodnie z art. 112 kc., pojawia się kilkakrotnie w przepisach o kontroli koncentracji. W pierwszej kolejności warto sięgnać do przepisu art. 14 pkt 2 u.o.k.k., na gruncie którego nie jest jasnym, jakie są skutki upływu rocznego terminu dla obowiązków i odpowiedzialności przedsiębiorców dokonujących koncentracji, wobec czego należałoby postulować rozwiązanie tej kwestii w ustawie przy okazji najbliż- 
szej jej nowelizacji. Otóż zgodnie z tym przepisem nie podlega zgłoszeniu zamiar koncentracji, polegającej na czasowym nabyciu lub objęciu przez instytucję finansową akcji albo udziałów w celu ich odsprzedaży, jeżeli przedmiotem działalności gospodarczej tej instytucji jest prowadzone na własny lub cudzy rachunek inwestowanie w akcje albo udziały innych przedsiębiorców, pod warunkiem, że odsprzedaż ta nastapi przed upływem roku od dnia nabycia lub objęcia (o ile termin ten nie zostanie przedłużony na podstawie art. 23 u.o.k.k.), oraz że instytucja ta nie wykonuje praw z tych akcji albo udziałów, z wyjątkiem prawa do dywidendy lub wykonuje te prawa wyłącznie w celu przygotowania odsprzedaży całości lub części przedsiębiorstwa, jego majątku lub tych akcji albo udziałów. Niektórzy autorzy przyjmują, że bezskuteczny upływ terminu rocznego w opisanej sytuacji spowoduje „konieczność zgłoszenia i poddania kontroli zamiaru” koncentracji ${ }^{13}$. Inni dodają, że „obowiązek zgłoszenia powstaje w pierwszym dniu po upływie wspomnianego terminu"14.

Należy jednak mieć na uwadze, że zgłoszeniu Prezesowi UOKiK podlega, pod rygorem nałożenia kary pieniężnej, zamiar koncentracji przedsiębiorców, nie zaś fakt dokonania tej czynności ${ }^{15}$. Tym samym należałoby uznać, że skutkiem bezskutecznego upływu terminu rocznego, o którym mowa w art. 14 pkt 2 u.o.k.k., jest to, że koncentracja staje się koncentracją dokonaną ( $\mathrm{z}$ dniem nabycia lub objęcia akcji albo udziałów) bez zgody Prezesa UOKiK ze wszystkimi tego konsekwencjami, $\mathrm{w}$ tym wynikającymi z art. 106 ust. 1 pkt 3 u.o.k.k. oraz art. 21 ust. $2 \mathrm{w}$ zw. $\mathrm{z}$ art. 21 ust. 4 u.o.k.k. Zatem aby uniknąć tych konsekwencji, przedsiębiorca powinien w dacie końcowej omawianego rocznego terminu (o ile termin ten nie zostanie przedłużony na podstawie art. 23 u.o.k.k.) uzyskać już decyzję Prezesa UOKiK w sprawie zgody na dokonanie koncentracji, a nie dopiero o wydanie takiej zgody występować. Innymi sposobami ,ucieczki” przed odpowiedzialnością będą: uzyskanie przedłużenia terminu na podstawie art. 23 u.o.k.k. albo wreszcie zbycie odpowiedniej części akcji czy udziałów (tak, by instytucja finansowa nie sprawowała kontroli nad daną spółką) przed upływem terminu rocznego.

W przepisach o kontroli koncentracji obserwujemy również zastosowanie terminu jako czynnika „sanującego” koncentrację dokonaną bez zgody Prezesa UOKiK. Zgodnie z art. 21 ust. 3 u.o.k.k. decyzja nakazująca „dekoncentrację” przedsiębiorców nie może być wydana po upływie 5 lat od dnia dokonania koncentracji. Trudno zgodzić się $\mathrm{z}$ wyrażonym $\mathrm{w}$ doktrynie ${ }^{16}$ poglądem, iż termin ten należy liczyć

\footnotetext{
13 T. Skoczny, (w:) red. T. Skoczny, Ustawa o ochronie..., s. 811.

14 K. Kohutek, (w:) K. Kohutek, M. Sieradzka, Ustawa o ochronie konkurencji i konsumentów. Komentarz, Warszawa 2008, s. 491.

15 Tak wyrok Sądu Ochrony Konkurencji i Konsumentów z dnia 12 listopada 2003 r., XVII Ama 129/02, „Wokanda” 2004, nr 7-8, s. 98.

16 P. Lissoń, (w:) red. T. Skoczny, Ustawa o ochronie..., s. 918.
} 
W oparciu o treść art. 57 k.p.a. ${ }^{17}$ Po pierwsze, kodeks postępowania administracyjnego nie reguluje obliczania terminów określonych w latach. Po drugie, termin 5letni $\mathrm{z}$ art. 21 ust. 3 u.o.k.k. nie jest terminem procesowym, a to do obliczania terminów procesowych stosuje się na gruncie prawa antymonopolowego art. 57 k.p.a. poprzez odesłanie z art. 83 u.o.k.k. Z kolei wątpliwości nie budzi, że aby nie zaistniały skutki z art. 21 ust. 3 u.o.k.k., Prezes UOKiK musi przed upływem 5-letniego terminu decyzję wydać (nie wystarczy samo wszczęcie postępowania), natomiast nie musi dokonać jej doręczenia ani tym bardziej nie musi ona stać się ostateczna. $\mathrm{Z}$ punktu widzenia zasady pewności obrotu lepszym byłoby przyjęcie rozwiązania zakładającego obowiązek doręczenia decyzji przed upływem wskazanego terminu.

Kolejny wątek, który warto poruszyć przy tematyce kontroli koncentracji, stanowi termin (czas) obowiązywania decyzji. W literaturze przyjęło się termin 2-letni na dokonanie koncentracji, liczony od daty wydania decyzji w sprawie bezwarunkowej zgody na koncentrację, a wynikający $\mathrm{z}$ art. 22 ust. 1 u.o.k.k. (ewentualnie termin 3-letni w razie przedłużenia terminu 2-letniego o rok), określać mianem ,terminu obowiązywania decyzji” "18. Określenie to jest skrótem myślowym, gdyż decyzja w sprawie bezwarunkowej zgody na koncentrację nie jest aktem administracyjnym opatrzonym postanowieniem dodatkowym w postaci terminu. Mianem terminu obowiązywania decyzji określa się raczej klauzulę dodatkową zawartą w decyzji, a uzależniającą uprawnienia bądź obowiązki wynikające z decyzji od upływu czasu.

O terminie obowiązywania decyzji mówi się w przypadku decyzji wydawanych na czas oznaczony. Natomiast w przypadku określonym w art. 22 ust. 1 u.o.k.k. mamy do czynienia nie $\mathrm{z}$ terminem obowiązywania decyzji, lecz z ustawowo określonym momentem wygaśnięcia decyzji z mocy samego prawa (ex lege), bez konieczności podejmowania $\mathrm{w}$ tym zakresie jakichkolwiek czynności przez organ administracyjny. Zatem to ustawa niejako z góry przesądza o chwili ustania uprawnienia do dokonania koncentracji przez beneficjentów zgody Prezesa UOKiK, natomiast bynajmniej nie oznacza to, że decyzja wydawana jest na czas oznaczony. Wydaje się, że regulacja art. 22 ust. 1 u.o.k.k. jest racjonalna, natomiast nie można wykluczyć, że w miarę przeobrażeń współczesnej gospodarki, w tym dynamizacji rynków, termin 2-letni na dokonanie koncentracji może stać się zbyt długim i konieczna stanie się wówczas ingerencja ustawodawcy w omawianą normę celem dostosowania terminu do realiów gospodarczych.

Inny przykład wpływania czynnika czasu na uprawnienia stron zawarto $\mathrm{w}$ art. 97 ust. 1 u.o.k.k. Zgodnie z tym przepisem przedsiębiorcy, których zamiar koncentra-

\footnotetext{
17 Ustawa z dnia 14 czerwca 1960 r. - Kodeks postępowania administracyjnego, Dz.U. z 2000 r. Nr 98 , poz. 1071 z późn. zm.

18 Red. C. Banasiński, E. Piontek, Ustawa o ochronie..., s. 385. Inne określenie to „termin ważności decyzji”; zob. P. Lissoń, (w:) red. T. Skoczny, Ustawa o ochronie..., s. 923.
} 
cji podlega zgłoszeniu, są obowiązani do wstrzymania się od dokonania koncentracji do:

- czasu wydania przez Prezesa UOKiK decyzji, lub

- upływu terminu, w jakim decyzja powinna zostać wydana.

Tym samym, jeśli Prezes UOKiK pozwoli, aby co do zasady 2-miesięczny termin na wydanie decyzji, liczony od daty wszczęcia postępowania, upłynął bezskutecznie, przedsiębiorcy będą uprawnieni do dokonania koncentracji, której zamiar zgłosili Prezesowi UOKiK. Bezskuteczny upływ terminu przewidzianego w ustawie na zakończenie postępowania (terminu procesowego) wywołuje zatem skutki materialnoprawne, stąd też termin ten należy traktować również jako termin prawa materialnego.

Domniemanie wydania decyzji w sprawie zgody na dokonanie koncentracji z chwilą upływu terminu wyznaczonego w ustawie na ukończenie postępowania powoduje, że w praktyce w efekcie strona (strony) postępowania nie uzyskuje decyzji. Trudno tu nawet mówić o surogacie decyzji. Ziszcza się po prostu skutek prawny, jaki ustawa wiąże z brakiem rozstrzygnięcia sprawy przez Prezesa UOKiK w terminie. Taka fikcja decyzji pozytywnej służyć ma zapobieganiu bezczynności organu antymonopolowego. Ustawa gwarantuje w ten sposób przedsiębiorcom, że postępowanie, w którym organ antymonopolowy rozpatruje zgłoszenie koncentracji, zakończy się rozstrzygnięciem sprawy w terminie. Powyższe rozwiązanie jest zdecydowanie lepszym niż zwykłe przyznanie przedsiębiorcom środków zwalczania bezczynności organów. Ustawodawca wciąż w niewielu przypadkach dopuszcza fikcję decyzji, przykładem mogą być tu indywidualne interpretacje podatkowe. Jednak w przypadku koncentracji milczenie organu, które nie byłoby obwarowane w ustawie domniemaniem wydania decyzji, mogłoby skutkować rozległymi szkodami dla przedsiębiorców zamierzających dokonać koncentracji, czy nawet dla całego rynku właściwego.

V. Nawiązując do wspomnianego wyżej wprowadzania do decyzji Prezesa UOKiK czynnika czasu w postaci postanowienia dodatkowego - terminu (czasu) obowiązywania decyzji, wskazać należy na art. 89 u.o.k.k. Jeżeli w toku postępowania antymonopolowego zostanie uprawdopodobnione, że dalsze stosowanie zarzucanej praktyki ograniczającej konkurencję może spowodować poważne i trudne do usunięcia zagrożenia dla konkurencji, Prezes UOKiK przed zakończeniem postępowania antymonopolowego może, w drodze decyzji (tzw. decyzji tymczasowej), zobowiązać przedsiębiorcę, któremu jest zarzucane stosowanie praktyki, do zaniechania określonych działań w celu zapobieżenia tym zagrożeniom. W decyzji tej Prezes UOKiK określa czas jej obowiązywania, który następnie kolejną decyzją (decyzjami) może przedłużać. W świetle art. 107 § 2 k.p.a. przepisy szczególne mogą określać także składniki, które powinna zawierać decyzja, inne niż oznaczenie 
organu administracji publicznej, data wydania, oznaczenie stron, powołanie podstawy prawnej, rozstrzygnięcie, uzasadnienie faktyczne i prawne, pouczenie, podpis z podaniem imienia i nazwiska oraz stanowiska służbowego osoby upoważnionej do wydania decyzji. Czas obowiązywania jest takim właśnie innym składnikiem, który powinien znaleźć się w decyzji tymczasowej. Tylko w tym czasie decyzja wywołuje skutki prawne, tylko w tym czasie trwają wynikające z niej obowiązki przedsiębiorcy. Pewną komplikację w powyższej konstrukcji tworzy jednak zdanie drugie w art. 89 ust. 2 u.o.k.k. Wynika z niego, że decyzja tymczasowa obowiązuje nie dłużej niż do czasu wydania decyzji kończącej postępowanie w sprawie. Co jednak dzieje się z decyzją tymczasową z chwilą wydania decyzji merytorycznej? Problemem statusu prawnego decyzji tymczasowej po wydaniu decyzji merytorycznej zajmował się Sąd Najwyższy ${ }^{19}$. W ocenie Sądu decyzja tymczasowa nie traci mocy, nie staje się decyzją nieistniejącą ani nie wygasa z mocy prawa. Tym samym formalnie decyzja obowiązuje, dopóki nie zostanie uchylona bądź też zmieniona w stosownym postępowaniu. Należałoby postulować zmianę przepisów u.o.k.k. tak, aby ustawa wyraźnie stanowiła, że decyzja tymczasowa w opisanym przypadku wygasa.

Warto dodać, że termin jako postanowienie dodatkowe w decyzji rzadziej odnosi się do bytu (istnienia) i mocy wiążącej decyzji, częściej zaś odnosi się do treści decyzji i jest stosowany jako swego rodzaju granica dla praw lub obowiązków strony ${ }^{20}$. Przykłady tego drugiego zastosowania terminu na gruncie ustawy o ochronie konkurencji i konsumentów stanowią przepisy art. 12 i 19 u.o.k.k.

Pierwszy z nich dotyczy tzw. decyzji zobowiązującej, którą Prezes UOKiK może wydać, jeżeli w toku postępowania antymonopolowego zostanie uprawdopodobnione - na podstawie okoliczności sprawy, informacji zawartych w zawiadomieniu lub będących podstawą wszczęcia postępowania z urzędu - że został naruszony zakaz praktyk ograniczających konkurencję, a przedsiębiorca, któremu jest zarzucane naruszenie tego zakazu, zobowiąże się do podjęcia lub zaniechania określonych działań zmierzających do zapobieżenia tym naruszeniom. W drodze takiej decyzji Prezes UOKiK zobowiązuje przedsiębiorcę do wykonania tych zobowiązań, przy czym może w decyzji może określić termin wykonania zobowiązań (składnik fakultatywny decyzji). Obligatoryjnym składnikiem decyzji jest natomiast obowiązek składania w wyznaczonym terminie informacji o stopniu realizacji zobowiązań. A zatem decyzja zobowiązująca zawsze określa termin, w którym obowiązek informacyjny musi być wykonany (wykonywany) i dodatkowo może zawierać termin wykonania zobowiązań przez stronę. W praktyce więc brak określenia terminu wykonania zobowiązań przez stronę będzie skutkował koniecznością dążenia do wykonania ich w terminie umożliwiającym terminowe wykonanie obowiązków spra- 
wozdawczych wobec Prezesa UOKiK wynikających z decyzji. Terminy, o których mowa, mogą być oznaczone w różnorodny sposób - konkretną datą, liczbą dni, tygodni, miesięcy, lat, a nawet mniej precyzyjnie. Przykładowo w jednej z decyzji zobowiązujących Prezes UOKiK wyznaczył termin w sposób następujący: „najpóźniej do daty uprawomocnienia się niniejszej decyzji” ${ }^{21}$. W praktyce jednak jest to najczęściej data kalendarzowa.

Istotne podobieństwa do decyzji zobowiązującej - w zakresie dodatkowych postanowień operujących czynnikiem czasu - wykazuje decyzja w sprawie warunkowej zgody na dokonanie koncentracji, o której mowa w art. 19 u.o.k.k. Od decyzji zobowiązującej odróżnia decyzję w sprawie warunkowej zgody na dokonanie koncentracji to, że zarówno termin spełnienia warunków nałożonych przez Prezesa UOKiK, jak i termin wykonania (wykonywania) obowiązku informacyjnego są obligatoryjnymi składnikami decyzji. Rozwiązania zastosowane w obu przepisach nie budzą zastrzeżeń, można byłoby jedynie rozważyć zmianę w art. 12 u.o.k.k. w ten sposób, by również termin wykonania zobowiązań stanowił obligatoryjny składnik decyzji.

VI. W rozważaniach na temat czasu w prawie antymonopolowym nie może zabraknąć zagadnienia tzw. przedawnienia antymonopolowego. Podkreślenia przy tym wymaga, że przepisy dotyczące przedawnienia antymonopolowego, tj. art. 93 u.o.k.k. odnośnie do praktyk ograniczających konkurencję oraz art. 76 u.o.k.k. odnośnie do pozostałych naruszeń prawa antymonopolowego, umiejscowione w grupie przepisów o postępowaniu przed Prezesem UOKiK, ustanawiają instytucję przedawnienia wszczęcia postępowania administracyjnego (nie zaś przedawnienia orzekania we wszczętym postępowaniu). Drugi z wymienionych przepisów przewiduje termin 5-letni, liczony od końca roku, w którym dopuszczono się naruszenia przepisów ustawy albo uprawomocniła się decyzja o nałożeniu kary pieniężnej. Pierwszy z przepisów określa roczny termin przedawnienia, liczony od końca roku, w którym zaprzestano stosowania praktyk ograniczających konkurencję. Powyższy sposób liczenia terminów przedawnienia powoduje, że faktycznie terminy te są zawsze dłuższe niż 5 lat i 1 rok, w skrajnych przypadkach sięgać mogą odpowiednio niemalże 6 i 2 lat. Ustawa nie przewiduje żadnych przypadków przerwania biegu terminów przedawnienia (np. poprzez wszczęcie postępowania wyjaśniającego), nie ma też możliwości skracania ani wydłużania terminów przedawnienia.

Istotne znaczenie dla oceny przedawnienia wszczęcia postępowania w sprawach praktyk ograniczających konkurencję ma ustalenie daty zaprzestania praktyk. Zastrzeżenia może budzić pogląd, zgodnie z którym w przypadku porozumienia wielostronnego dopiero zaprzestanie uzgodnionych praktyk przez wszystkie strony 
porozumienia powoduje, że rozpoczyna się bieg terminu przedawnienia ${ }^{22}$. Takie podejście sankcjonuje swego rodzaju odpowiedzialność zbiorową stron, w tym tych $\mathrm{z}$ nich, które nie miały żadnego realnego wpływu na kontynuowanie zakazanych praktyk przez pozostałe strony porozumienia. Ustawowe sformułowanie ,zaprzestano ich stosowania" nie jest jednak na tyle precyzyjne, by w sposób niebudzący wątpliwości wynikało z niego, czy w przypadku praktyk kolektywnych chodzi o zaprzestanie stosowania praktyk przez wszystkie strony czy przez poszczególne strony. Cytowane słowa należałoby zastapić frazą w brzmieniu: ,przedsiębiorca zaprzestał ich stosowania".

VII. Na zakończenie jedynie zasygnalizuję kilka kwestii związanych z czasem w postępowaniu antymonopolowym. Można je ująć w dwie podstawowe grupy. Po pierwsze, przepisy u.o.k.k. ustanawiają terminy adresowane do organu antymonopolowego. $\mathrm{Z}$ jednej strony określają czas trwania postępowania. I tak postępowanie wyjaśniające (za wyjątkiem dotyczącego badania rynku) „nie powinno trwać dłużej niż 30 dni, a w sprawach szczególnie skomplikowanych - nie dłużej niż 60 dni od dnia jego wszczęcia" (art. 48 ust. 4 u.o.k.k.). Warto w tym miejscu zwrócić uwagę na błąd w cytowanym przepisie, spowodowany zbędną partykułą przeczącą „nie” przed wyrazem „dłużej”. Jej obecność powoduje, że z podwójnego zaprzeczenia: „nie powinno trwać” (...) „nie dłużej”, uzyskujemy dyrektywę, zgodnie z którą postępowanie wyjaśniające $\mathrm{w}$ sprawach szczególnie skomplikowanych powinno trwać dłużej niż 60 dni, co jest oczywistym błędem, który powinien być naprawiony przy najbliższej nowelizacji u.o.k.k. Z kolei postępowanie antymonopolowe w sprawach praktyk ograniczających konkurencję powinno być zakończone nie później niż w terminie 5 miesięcy od dnia jego wszczęcia (art. 92 u.o.k.k.).

Terminy powyższe mają charakter jedynie instrukcyjny. To odróżnia je od terminu zakończenia postępowania w sprawie koncentracji, określonego w art. 96 u.o.k.k., który obwarowany jest domniemaniem wydania decyzji na wypadek bezczynności Prezesa UOKiK. Nie można jednak wykluczyć, że z biegiem czasu również na gruncie prawa antymonopolowego pojawią się postulaty analogiczne do głoszonych obecnie przez Komisję Kodyfikacyjną Prawa Karnego. Żąda ona, aby wprowadzić przepisy, w świetle których, jeżeli w ciagu roku od postawienia zarzutów prokurator nie zakończy postępowania przygotowawczego, to sąd umorzy postępowanie karne na wniosek podejrzanego ${ }^{23}$.

$\mathrm{Z}$ drugiej strony, ustawa określa terminy wykonania pewnych czynności przez organ antymonopolowy. Przepis art. 95 ust. 1 pkt 2 u.o.k.k. daje Prezesowi UOKiK

22 C. Banasiński, E. Piontek (red.), Ustawa o ochronie..., s. 775.

23 Por. też art. 38 ust. 1 hiszpańskiej ustawy nr 15/2007 z dnia 3 lipca 2007 r. o konkurencji, wersja angielska do pobrania na: http://www.cncompetencia.es/Inicio/Legislacion/NormativaEstatal/tabid/81/Default.aspx (,,The course of the maximum period of eighteen months established in Section 1 of Article 36 to resolve sanctioning proceedings regarding agreements and prohibited practices shall determine the expiry of proceedings"). 
prawo zwrotu zgłoszenia zamiaru koncentracji w terminie 14 dni, jeżeli zgłoszenie nie spełnia warunków, jakim powinno odpowiadać. Po upływie tego terminu Prezes UOKiK nie może zwrócić zgłoszenia, a może jedynie wezwać zgłaszającego zamiar koncentracji do usunięcia wskazanych braków w zgłoszeniu lub uzupełnienia $\mathrm{w}$ nim niezbędnych informacji w wyznaczonym terminie i zwrócić zgłoszenie zamiaru koncentracji, jeżeli pomimo wezwania zgłaszający zamiar koncentracji nie usunie wskazanych braków lub nie uzupełni informacji w wyznaczonym terminie.

Również przepisy o kontroli w toku postępowania przed Prezesem UOKiK zakreślają mu pewne terminy. Przepis art. 105a ust. 7 u.o.k.k. ogranicza termin wręczenia upoważnienia do kontroli kontrolowanemu, który nie był obecny, gdy kontrolujący stawił się u kontrolowanego do przeprowadzenia czynności kontrolnych. Regulacje te należy uznać za należycie zabezpieczające prawa przedsiębiorcy.

Oprócz terminów adresowanych do organu antymonopolowego ustawa formułuje również szereg terminów adresowanych do strony. Przepisy art. 81 ust. 1 i 5 u.o.k.k. ustanawiają terminy wnoszenia środków zaskarżenia decyzji i postanowień Prezesa UOKiK. Oczywiście, odmiennie niż w przypadku ustanawianych dla organu terminów instrukcyjnych, upływ tych terminów powoduje utratę uprawnienia przez stronę, chyba że strona skutecznie skorzysta z możliwości wnioskowania o przywrócenie terminu. $Z$ kolei art. 105k ust. 2 przewiduje 7-dniowy termin na złożenie zastrzeżeń do protokołu kontroli, liczony od daty przedstawienia kontrolowanemu protokołu kontroli do podpisu. Nie wydaje się, aby regulacje powyższe wymagały obecnie nowelizacji.

VIII. Czas, by podsumować zebrane powyżej uwagi o czasie. Skupiły się one jedynie na części zagadnień związanych z czynnikiem czasu w prawie antymonopolowym. Nawet przy tak pobieżnym zarysowaniu wskazanej problematyki łatwo można dostrzec, że element czasu wykorzystywany jest w przepisach prawa antymonopolowego do wielu celów. Wpleciony jest w konstrukcję szeregu instytucji prawa antymonopolowego. W zasadzie w przypadku połowy analizowanych przypadków element czasu został użyty w sposób niebudzący zastrzeżeń. Jednocześnie jednak pozostaje jeszcze druga połowa analizowanych regulacji, do których zgłoszone zostały powyżej pewne uwagi i propozycje de lege ferenda. Okazuje się bowiem, że ustawodawca niekiedy używa w niedoskonały sposób pojęć służących określeniu czasu. Zdiagnozowano również problem z umieszczeniem w czasie punktu odniesienia służącego stosowaniu zasady de minimis. W kilku przypadkach ustawodawca nie określił precyzyjnie skutków prawnych upływu określonych terminów. Wreszcie przepis dotyczący przedawnienia antymonopolowego nie jest na tyle precyzyjny, by przedsiębiorcy dopuszczający się kolektywnych praktyk ograniczających konkurencję mogli mieć pewność co do obliczania terminu przedawnienia. Powyższe braki wymagają poświęcenia im uwagi w toku prac nad najbliższą nowelizacją ustawy o ochronie konkurencji i konsumentów. 


\title{
THE TIME FACTOR IN ANTITRUST LAW
}

\author{
SUMMARY
}

Various institutions of antitrust law may be analysed in one frame because of the factor of time that is common to all those institutions. There are four possible levels of review and analysis. These are substantive antitrust law, procedural antitrust law, structural antitrust law and history of antitrust law. This paper is not meant to be a complete analysis, but rather an overview. It focuses on substantive antitrust law and to a lesser extent on procedural antitrust law. It is also limited to a narrow context of Polish law, excluding European Union antitrust law.

This paper attempts to present the various dimensions of time to be carefully considered for decision-making and law-making. The main aim of the paper is to understand the meaning of those provisions of antitrust law that are construed using time factors. It includes considerations such as relevant market, de minimis rule, fines, deadlines etc. The paper also discusses the question of limitation.

The author also tries to fill diagnosed gaps by de lege ferenda proposals. 